\section{Sweetpotato Whitefly, Drought Stress, and Leaf Silvering of Squash}

\author{
Harry S. Paris ${ }^{1}$, Peter J. Stoffella, and Charles A. Powell \\ University of Florida, Institute of Food and Agricultural Sciences, Agricultural \\ Research and Education Center, P.O. Box 248, Fort Pierce, FL 34954
}

Additional index words. Bemisia tabaci, water deficit, Cucurbita pepo, squash silverleaf

Abstract. Summer squash (Cucurbita pepo L.) plants were grown in pots with high $(290 \%$ capacity) or low (45\% to $70 \%$ of capacity) soil moisture. The plants were exposed or not exposed to sweetpotato whiteflies (Bemisia tabaci Genn.). Only the plants exposed to whiteflies developed leaf silvering. Silvering was more severe in plants subjected to low soil moisture.

Leaf silvering was initially described as a severe disorder of summer squash in Israel (Ayyalon, 1969; Be'eri and Kapuler, 1963). In mild cases, symptoms are silver regions on the adaxial leaf surface alongside major veins. In moderate cases, most or all leaf veins are paralleled with silver. In severe cases, the entire adaxial leaf blade surface is silvered and petioles and stems are whitened (Burger et al., 1983; Paris et al., 1987) and the few, if any, fruit produced are pale. Photosynthesis rate in completely silvered leaves was reported to be $30 \%$ lower than in green leaves at saturating or above-saturating light (Burger et al., 1988). Although the cause of squash leaf silvering in Israel was unknown, low soil moisture was reported to increase its severity (Paris et al., 1987).

Silverleaf was recently reported to be a serious malady of squash in Florida (Maynard and Cantliffe, 1989; Simons et al., 1989) and California (Cohen et al., 1992), and of pumpkin [ C. moschata (Duch. ex Lam.) Duch. ex Poir.] in Puerto Rico (Segarra-Carmona et al., 1990). Researchers reported that expression of the disorder depended on the presence of the sweetpotato whitefly (SPWF) (Bharanathan et al., 1990; Cohen et al., 1992; Schuster et al., 1991; Segarra-Carmona et al., 1990; Yokomi et al., 1990). Squash leaf silvering symptoms are identical in Israel and Florida (H.S.P., unpublished observations).

In Israel, squash leaf silvering is most prevalent in the late summer and fall (Ayyalon, 1969; Burger et al., 1983), when SPWFs are most ubiquitous. Conversely, there have been observations from commercial squash and pumpkin fields suggesting that there is a relationship between leaf silvering severity and drought stress in Florida (Simons et al., 1989) and Puerto Rico (Segarra-Carmona et al.,

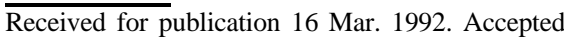
for publication 3 Sept. 1992. Florida Agricultural Experiment Station Journal Series no. R-02221. The cost of publishing this paper was defrayed in part by the payment of page charges. Under postal regulations, this paper must therefore be hereby marked advertisement solely to indicate this fact.

'On sabbatical. Permanent address: Dept. of Vegetable Crops, Agricultural Research Organization, Newe Ya'ar Experiment Station, P.O. Haifa, Israel.
}

1990). The objective of the present work was to observe how SPWFs and drought stress affect silvering when both are introduced into the same experiment.

A potting mix [Terra-lite Metro-mix growing medium 220 (W.R. Grace, Cambridge, Mass.)] was dried at 51C. One-liter Styrofoam cups $(16.7 \mathrm{~cm}$ high, $11.5 \mathrm{~cm}$ wide at the top, and $7.5 \mathrm{~cm}$ wide at the base) were filled with placed in trays and watered until the mix was saturated $(\approx 36 \mathrm{~h})$, then allowed to drain for several minutes and reweighed. The weight of water absorbed by the mix was calculated by subtraction, a procedure that made it possible to monitor the two soil-moisture treatmentshigh (at least $90 \%$ of capacity) or low ( $45 \%$ to $70 \%$ of capacity).

Seeds of 'Clarita' (Petoseed, Saticoy, Calif.), a cultivar of the vegetable-marrow group of $C$. pepo (Paris, 1986) were sown three per pot on 28 Aug. and again on 6 Dec. 1991 in a glasshouse at the Agricultural Research and Education Center, Fort Pierce, Fla. The greenhouse had been whitewashed for the August sowing, but the whitewash was removed before the December sowing. The pots were placed in boxes covered with whiteflyimpervious mesh. Two weeks after sowing, the plants were thinned to one per pot. SPWFs that had been raised on 'Senator' (C. pepo, zucchini group; Paris, 1986) were sedated at $-20 \mathrm{C}$ for $5 \mathrm{~min}$ and placed in a $3.5-\mathrm{cm}$-diameter parts holding basket (Alpha Supply, Bremerton, Wash.), 10 to 15 SPWFs per basket in the first experiment and $\geq 20$ per basket in the second. Foam rubber padding had been cemented around the edge of the baskets for cushioning, and the mesh of the basket had been sealed with rubber cement to render it impervious to the SPWFs. The baskets were clamped to the first true leaf of each plant; the revived SPWFs had access only to the abaxial surface of the leaf. To initiate the low soil moisture treatment, water was withheld from plants beginning 5 (first experiment) or 3 (second experiment) days before their exposure to SPWFs.

Soil moisture was monitored by weighing individual pots every 2 to 4 days. With the low soil moisture treatment, moisture levels dropped to as low as $45 \%$ to $50 \%$ of capacity the dry mix and weighed. They were then between waterings. At weighing, enough water was added to restore soil moisture to $70 \%$ of capacity. With the high soil moisture treatment, enough water was added at and between weighings to maintain soil moisture at $90 \%$ to $100 \%$ of capacity. Plant weight, which of necessity was included in pot weight, was not taken into account in maintaining soil moisture. At the conclusion of the experiments, weight of the aerial part of the plant was $\approx 2 \%$ of the weight of the water in the soil at $100 \%$ of capacity.

All plants were fertilized with Hoagland solution (first experiment) or with 20N-8.6P$16.6 \mathrm{~K}$ (plus micronutrients) fertilizer (second experiment). Because the first (SPWF-exposed) leaf senesced in some plants before the seventh leaf opened, data are presented for the first six leaves. Individual leaves were scored for silvering severity according to the 0 (asymptomatic) to 5 (completely silvered) scale described and illustrated by Paris et al. (1987).

Along with the plants bearing basketed SPWFs in the first experiment, an equal number of plants not exposed to whiteflies was placed in the SPWF-impervious boxes, half with low and half with high soil moisture. The four treatments (SPWFs-low soil moisture; SPWFs-high soil moisture; no SPWFs-low soil moisture; no SPWF-high soil moisture) of the first experiment were arranged in a randomized block design with 11 replicates. The two treatments (SPWFs-low moisture and SPWFs-high moisture) of the second experiment were arranged in a randomized block (paired) design with 16 replicates.

All of the plants exposed to SPWFs (both experiments) developed silvering. Plants not exposed to SPWFs (first experiment) did not develop silvering; therefore, the two no-SPWF treatments were eliminated from the analysis of variance.

Silvering began to appear 15 days after exposure to SPWFs (4 weeks after sowing) (Table 1). The first (exposed) leaf and the two or three succeeding leaves did not exhibit silvering.

Chronologically, silvering appeared sooner in the low soil moisture treatment in the second experiment (Table 2) but not in the first (Tables 1 and 2). This difference may have been due to excessive etiolation of the plants in the first experiment or to the earlier initiation (5 days, instead of three, before whitefly exposure) of the low soil moisture treatment in that experiment. Plant ontogeny was slowed by low soil moisture early in the first experiment, but later on and less so in the second experiment.

Ontogenically, silvering appeared one leaf earlier in the plants grown in low soil moisture than in the plants grown in high soil moisture in both experiments (Tables 1 and 2). Silvering became more severe in successive leaves, but was significantly higher in the low soil moisture treatments in both experiments. In plants grown in low soil moisture, silvering first appeared one leaf earlier in the second experiment than in the first experiment. In the second experiment, even plants grown in high soil moisture averaged moderately severe 
Table 1. Silvering in squash plants grown under low or high soil moisture and exposed to whiteflies, first experiment.

\begin{tabular}{|c|c|c|c|c|c|c|}
\hline \multirow[b]{2}{*}{$\begin{array}{l}\text { Soil } \\
\text { moisture }\end{array}$} & \multirow[b]{2}{*}{$\begin{array}{c}\text { Days } \\
\text { to first } \\
\text { silvering }\end{array}$} & \multirow[b]{2}{*}{$\begin{array}{c}\text { First } \\
\text { silvered } \\
\text { leaf }\end{array}$} & \multicolumn{4}{|c|}{ Degree of silvering ${ }^{2}$} \\
\hline & & & Leaves $1-4$ & Leaf 5 & Leaf 6 & $\begin{array}{r}\text { Mean of } \\
\text { leaves } \\
5 \text { and } 6\end{array}$ \\
\hline Low & 16.0 & 5.3 & 0.0 & 1.5 & 2.5 & 2.0 \\
\hline High & 15.3 & 6.2 & 0.0 & 0.5 & 1.1 & 0.8 \\
\hline$t$ & NS & $*$ & $\ldots$ & NS & $* *$ & $*$ \\
\hline
\end{tabular}

${ }^{2}$ Scale where $0=$ asymptomatic and 5 = completely silvered (after Paris et al.,1987).

${ }^{y}$ After exposure to whiteflies.

ws, ${ }^{* *}$ Nonsignificant or significant at $P=0.05$ or 0.01 , respectively.

Table 2. Silvering in squash plants grown under low or high soil moisture and exposed to whiteflies, second experiment.

\begin{tabular}{|c|c|c|c|c|c|c|c|}
\hline \multirow[b]{2}{*}{$\begin{array}{l}\text { Soil } \\
\text { moisture }\end{array}$} & \multirow[b]{2}{*}{$\begin{array}{c}\text { Days } \\
\text { to first } \\
\text { silvering }\end{array}$} & \multirow[b]{2}{*}{$\begin{array}{c}\text { First } \\
\text { silvered } \\
\text { leaf }\end{array}$} & \multicolumn{5}{|c|}{ Degree of silvering ${ }^{z}$} \\
\hline & & & Leaves 1-3 & Leaf 4 & Leaf 5 & Leaf 6 & $\begin{array}{c}\text { Mean of } \\
\text { leaves } \\
4-6\end{array}$ \\
\hline Low & 15.2 & 4.4 & 0.0 & 1.0 & 3.7 & 4.8 & 3.1 \\
\hline High & 17.1 & 5.3 & 0.0 & 0.0 & 1.4 & 4.0 & 1.8 \\
\hline & $* * *$ & $* * *$ & -.. & $* * * *$ & $* * *$ & * & $* * *$ \\
\hline
\end{tabular}

${ }^{2}$ Scale where $0=$ asymptomatic and $5=$ completely silvered (after Paris et al., 1987).

${ }^{y}$ After exposure to whiteflies.

${ }^{* * * * *}$ Significant at $P=0.05$ or 0.001 , respectively.

(grade 4) silvering in the sixth leaf. The generally more severe silvering in the second experiment may have been due to the greater number of SPWFs used. Another possibility is that removing the greenhouse whitewash increased light intensity, which tends to increase silvering (Cohen et al., 1992).

These results are consistent with the idea that SPWFs induce silvering and that drought stress, in their presence, exacerbates silvering. The results agree with the findings of others (Bharanathan et al., 1990; Cohen et al., 1992; Schuster et al., 1991; Yokomi et al., 1990) that SPWFs are needed for silvering to be manifested. Likewise, the results are consistent with work showing that silvering is exacerbated by low soil moisture (Paris et al., 1987).

Some researchers have suggested that squash leaf silvering is exacerbated by high temperatures (Be'eri and Kapuler, 1963). Others have shown it to be exacerbated by high light intensity and long light duration (Cohen et al., 1992) or by particular cultural factors (Burger et al., 1983). Burger et al. (1983) observed an association between silvering and turgor loss. Low soil moisture, high temperatures, high light intensity, and long light duration all tend to increase plant water deficit or drought stress in the broad sense. Cultural practices that decrease SPWF population, decrease plant water deficit, or both may help lessen the severity of squash leaf silvering.

\section{Literature Cited}

Ayyalon, A. 1969. Giddul qishu'im yeruqqim lizu (Growing green summer squash for export). Publication 68/110/19, Agr. Ext. Serv., Israel Min. of Agr., Tel Aviv.
Be'eri, Y. and B. Kapuler. 1963. Qishu (Summer squash), p. 235-240. In: Y.M. Margalit (ed.). Giddul yeraqot (Growing of vegetables). Part B. Sifriyyat Hassadeh Pnbl., Tel Aviv.

Bharanathan, N., W.R. Graves, K.R. Narayanan, D.J. Schuster, H.H Bryan, and R.T McMillan, Jr. 1990. Association of double-stranded RNA with whitefly-mediated silvering in squash. Plant Pathol. 39:530-538.

Burger, Y., H.S. Paris, H. Nerson, Z. Karchi, and M. Edelstein. 1983. Overcoming the silvering disorder of Cucurbita. Cucurbit Genet. Coop. Rpt. 6:70-71.

Burger, Y., A. Schwartz, and H.S. Paris. 1988. Physiological and anatomical features of the silvering disorder of Cucurbita. J. Hort. Sci. 63:635-640.

Cohen, S., J.E. Duffus, and H.Y. Liu. 1992. A new Bemisia tabaci biotype in the southwestern United States and its role in silverleaf of squash and transmission of lettuce infectious yellows virus. Phytopathology 82:86-90.

Maynard, D.N. and D.J. Cantliffe. 1989. Squash silverleaf and tomato irregular ripening: New vegetable disorders in Florida. Veg. Crops Fact Sheet VC-37, Coop. Ext. Serv., Univ. of Florida, Gainesville.

Paris, H.S. 1986. A proposed subspecific classification for Cucurbita pepo. Phytologia 61:133-138.

Paris, H.S., H. Nerson, and Y. Burger. 1987. Leaf silvering of Cucurbita. Can. J. Plant Sci. 67:593598.

Schuster, D.J., J.B. Kring, and J.F. Price. 1991. Association of the sweetpotato whitefly with a silverleaf disorder of squash. HortScience 26:155-156.

Segarra-Carmona, A.E., J. Bird, J. Escudero, G. Fornaris-Rullan, and R.A. Franqui. 1990. Silvering of Cucurbita moschata (Duchesne) Poir. associated with Bemisia tubaci Genn. (Homoptera: Aleyrodidae) in Puerto Rico. J. Agr. Univ. Puerto Rico 74:477-478.

Simons, J.N., P.J. Stoffella, K.D. Shuler, and R.N. Raid. 1989. Silver-leaf of squash in south Florida. Proc. Fla. State Hort. Soc. 101(1988):397-399.

Yokomi, R.K., K.A. Hoelmer, and L.S. Osborne. 1990. Relationships between the sweetpotato whitefly and the squash silverleaf disorder. Phytopathology 80:895-900. 